\title{
GAMBARAN KARIES GIGI PADA PASIEN KARYAWAN PT FREEPORT INDONESIA BERDASARKAN KARAKTERISTIK DI RUMAH SAKIT TEMBAGAPURA KABUPATEN MIMIKA PAPUA TAHUN 2018-2019
}

\author{
Hirwatu Markus ${ }^{1)}$, I Ketut Harapan ${ }^{2)}$, Jean Henry Raule ${ }^{3)}$ \\ 1)RS.Tembagapura Jl.Tembagapura Raya Kab.Mimika Propinsi Papua \\ 2,3)Jurusan Keperawatan Gigi Poltekkes Kemenkes Manado Jl.RW Monginsidi Malalayang II
}

Email : iketutharapan@gmail.com

\begin{abstract}
ABSTRAK
Pendahuluan : Karies Gigi merupakan penyakit pada jaringan gigi yang diawali dengan terjadinya kerusakan jaringan yang dimulai dari permukaan gigi (Pit, Fissure, dan daerah interproximal), kemudian meluas kearah pulpa. Karies gigi dapat dialami oleh setiap orang dan juga dapat timbul pada satu permukaan gigi atau lebih serta dapat meluas kebagian yang lebih dalam dari gigi, misalnya dari enamel ke dentin atau pulpa. Tujuan : Penelitian ini bertujuan untuk mengetahui gambaran karies gigi pada kunjungan pasien karyawan PT Freeport Indonesia di Rumah Sakit Tembagapura tahun 2018-2019. Metode : Jenis penelitian yang digunakan adalah penelitian deskriptif dengan menggunakan data sekunder berupa buku register penggunjung Instalasi gigi dan mulut di Rumah Sakit PT. Freeport Indonesia di Tembagapura. Penelitian dilaksanakan pada bulan Mei 2020 dengan jumlah sampel 14.372 orang Hasil : Hasil penelitian yang didapatkan menunjukkan bahwa distribusi kunjungan pasien dengan penyakit karies gigi di Rumah Sakit PT Freeport Indonesia pada tahun 2018 sebanyak 6.671 pasien dan mengalami kenaikan pada tahun 2019 menjadi sebanyak 6.801 pasien. Kunjungan tertinggi pada kelompok umur 29-35 tahun yaitu sebesar 1.389 (20\%) pasien pada tahun 2018 dan 1.466 pasien (21\%) tahun 2019. Pasien dengan jenis kelamin laki-laki lebih besar dibandingkan dengan jenis kelamin perempuan, sebesar 5.560 pasien (83\%) tahun 2018 dan sebesar 5.586 pasien (82\%) pada tahun 2019. Kesimpulan : Distribusi karies pada pengunjung Instalasi gigi dan mulut tahun 2018-2019 mengalami peningkatan, di tahun 2019 dengan jumlah 6801 (51\%) kasus karies. Distribusi berdasarkan karakteristik umur tertinggi tahun 2018-2019 yaitu pada kelompok umur 29-35 tahun, pada tahun 2018 sebesar 1389 pasien (20,82\%) dan tahun 2019 sebesar 1466 pasien $(21,55 \%)$ Distribusi karies berdasarkan karakteristik jenis kelamin tertinggi yaitu pada Lakilaki tahun 2018 sebesar 5560 pasien (83,3\%) dan tahun 2019 sebesar 5586 pasien ( 82\%).
\end{abstract}

Kata Kunci: Penyakit Karies Gigi , Umur, Jenis kelamin

\begin{abstract}
Introduction: Dental caries is a disease in dental tissue that begins with tissue damage that starts from the tooth surface (Pit, fissure, and interproximal areas), then extends towards the pulp. Dental caries can be experienced by everyone and can also occur on one or more tooth surfaces and can extend to the deeper part of the teeth, for example from enamel to dentin or pulp. This study aims to determine the description of caries disease in PT. Freeport Indonesia based on characteristics at Tembagapura Hospital in 2018-2019. Purpose: This study aims to determine the description of dental caries during visits by PT Freeport Indonesia employees at Tembagapura Hospital in 2018-2019. Methods: This type of research is a descriptive study using secondary data in the form of a register book for visitors to the dental and oral installation at the PT. Freeport Indonesia in Tembagapura. Results: The results obtained showed that the distribution of patient visits with dental caries at the PT Freeport Indonesia Hospital in 2018 was 6,671 patients and an increase in 2019 to 6,801 patients. The
\end{abstract}


highest visits were in the 29-35 year age group, namely 1,389 (20\%) patients in 2018 and 1,466 patients $(21 \%)$ in 2019. Patients with male sex were greater than female, amounting to 5,560 patients (83\%) in 2018 and 5,586 patients $(82 \%)$ in 2019. Conclusion: The distribution of caries among visitors to dental and oral installations in 2018-2019 has increased, in 2019 the number of caries was $6801(51 \%)$. Distribution based on the highest age characteristics in 2018-2019, namely in the 29-35 year age group, in 2018 there were 1389 patients (20.82\%) and in 20191466 patients (21.55\%) Caries distribution based on the highest gender characteristics, namely In 2018 there were 5560 patients $(83.3 \%)$ and in 20195586 patients (82\%).

Keywords: Dental Caries, Age, Gender

\section{PENDAHULUAN}

Kesehatan gigi dan mulut merupakan bagian dari kesehatan tubuh yang dapat mempengaruhi kesehatan tubuh keseluruhan dan kualitas hidup. Kesehatan gigi dan mulut berarti bebas kanker tenggorokan, infeksi dan luka pada mulut, penyakit gusi, kerusakan gigi, kehilangan gigi dan penyakit lainnya. ${ }^{1}$

Karies Gigi merupakan penyakit pada jaringan gigi yang diawali dengan terjadinya kerusakan jaringan yang dimulai dari permukaan gigi (Pit, Fissure, dan daerah interproximal), kemudian meluas kearah pulpa. Karies gigi dapat dialami oleh setiap orang dan juga dapat timbul pada satu permukaan gigi atau lebih serta dapat meluas ke bagian yang lebih dalam dari gigi, misalnya dari enamel ke dentin atau pulpa. Terdapat berapa faktor yang menyebabkan terjadinya karies gigi diantaranya adalah karbohidrat mikroorganisme dan saliva permukaan dan anatomi gigi. ${ }^{2}$

Berdasarkan hasil survei Riset Kesehatan Dasar (Riskesdas) Nasional tahun 2018, prevalensi karies gigi di Indonesia cukup tinggi $(88,8 \%)$. Di Propinsi Papua masalah gigi dan mulut serta mendapatkan pelayanan dari tenaga medis gigi 45 kasus, 0,82 mendapat pelayanan, sedangkan proporsi perilaku menyikat gigi setiap hari pada penduduk umur > 3 tahun $54,4 \%$, penduduk yang melakukan gosok gigi pada waktu yang tepat adalah 5,8\%. Hal ini menunjukkan bahwa perilaku masyarakat Papua dalam menjaga kebersihan gigi dan mulut kurang baik. $^{3}$

P.T Freeport Indonesia merupakan salah satu perusahaan yang berkedudukan di Propinsi Papua. Berdasarkan data yang diperoleh dari laporan kunjungan pasien di Instalasi gigi dan mulut Rumah Sakit PT Freeport Indonesia pada tahun 2018 sebanyak 6.805 kunjungan pasien karyawan Freeport dan sebanyak 6.671 kasus dilakukan penambalan gigi. Dan meningkat pada tahun 2019 kunjungan pasien karyawan Freeport di Instalasi gigi dan mulut Rumah Sakit PT Freeport Indonesia sebanyak 7052 pasien dan sebanyak 6801 dilakukan penambalan gigi.

Karies gigi adalah proses penghancuran atau pelunakan dari email ataupun dentin. Proses penghancuran tersebut lebih cepat pada bagian dentin daripada email. Proses tersebut berlangsung terus sampai jaringan dibawahnya, dan ini adalah awal pembentukan. Telah banyak dilakukan penelitian oleh para ahli mengenai penyebab terjadinya karies, akan tetapi sampai saat ini masih dipercayai bahwa ada empat penyebab karies yaitu host atau gigi, mikroorganisme, plak, dan waktu.

a. Host 
Ada beberapa faktor yang dihubungkan degan gigi sebagai tuan rumah terhadap karies gigi salah satunya faktor morfologi gigi ukuran dan bentuk gigi). Pit dan fissure pada gigi sangat rentan terhadap karies terutama pit dan fissure yang dalam. Gigi yang berjejal dan struktur permukaan gigi yang abnormal. Kepadatan email, semakin banyak email mengandung mineral maka kristal email akan semakin padat dan email akan semakin resisten. Gigi susu lebih mudah terserang karies dibanding gigi tetap. ${ }^{4}$

b. Mikroorganisme

Streptococus mutans dan Lactobacillus merupakan mikroorganisme kariogenik karena mampu segera membuat asam dari karbohidrat yang dapat diragikan. Kuman-kuman tersebut dapat tumbuh subur dalam suasana asam dan dapat menempel pada permukaan gigi karena kemampuan membuat polisakarida ekstraseluler yang sangat lengket dari kerbohidrat makanan. Akibatnya, bakteribakteri terbantu untuk melekat pada gigi serta saling melekat satu sama lain sehingga plak makin tebal dan menghambat fungsi saliva dalam menetralkan plak tersebut. Jumlah Streptococus mutans lebih banyak terdapat pada seseorang yang mengalami karies aktif. ${ }^{5}$

c. Substrat

Faktor substrat atau diet dapat mempengaruhi pembentukan plak karena membantu perkembangbiakan dan kolonisasi mikroorganisme yang ada pada permukaan email. Selain itu dapat memengaruhi metabolisme bakteri dalam plak dengan menyediakan bahan-bahan yang diperlukan untuk memproduksi asam serta bahan lain yang aktif yang menyebabkan timbulnya karies. ${ }^{4}$

\section{d. Waktu}

Adanya kemampuan saliva untuk mengembalikan mineral selama berlangsungnya karies, menandakan bahwa proses karies mengalami demineralisasi dan remineralisasi yang silih berganti. Oleh karena itu apabila ada saliva di dalam lingkungan gigi, maka kerusakan tidak dapat terjadi secara cepat melainkan dalam hitungan bulan atau tahun. ${ }^{5}$

e. Saliva

Saliva berperan dalam proses terjadinya karies gigi. Rendahnya sekresi dan kapasitas bufer saliva menyebabkan berkurangnya kemampuan saliva dalam membersihkan sisa makanan, mematikan mikroorganisme, serta menetralkan $\mathrm{pH}$ saliva. Aliran saliva dapat menurunkan akumulasi plak pada permukaan gigi dan menaikkan tingkat pembersihan karbohidrat rongga mulut.

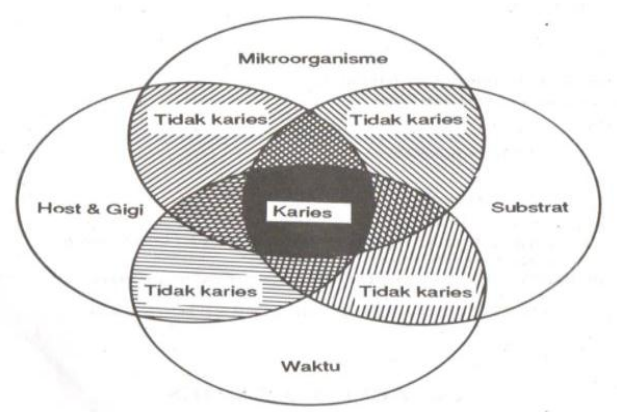

Gambar 2. Faktor etiologi terjadinya karies ${ }^{5}$

Karies gigi adalah kerusakan jaringan keras gigi yang disebabkan oleh asam yang dihasilkan dari interaksi mikroorganisme, saliva, dan sisa makanan. ${ }^{6}$

Menurut Tarigan (2012) ada beberapa faktor yang mempengaruhi terjadinya karies gigi, diantaranya sebagai berikut:

a. Keturunan, penelitian terhadap 12 pasang orang tua dengan keadaan gigi yang baik, terlihat bahwa anak-anak dari 11 pasang orang tua memiliki keadaan gigi geligi yang cukup baik;

b. Pengaruh ras terhadap terjadinya karies gigi ditemukan keadaan tulang suatu ras bangsa mungkin berhubungan dengan persentase karies yang semakin meningkat atau menurun; 
c. Jenis kelamin, yaitu persentase karies gigi pada wanita lebih tinggi dibandingkan dengan pria;

d. Usia sepanjang hidup dikenal 3 fase umur dilihat dari sudut gigi geligi, yaitu periode gigi campuran, disini molar 1 paling sering terkena karies, periode pubertas (remaja) usia antara 14-20 tahun;

e. Makanan sangat berpengaruh terhadap gigi dan mulut, pengaruh ini dapat dibagi menjadi dua yaitu makanan yang menghasilkan energi dan makanan yang bersifat membersihkan gigi dan makanan yang lunak dan melekat pada gigi bersifat merusak gigi;

f. Vitamin berpengaruh pada proses terjadinya karies gigi, terutama pada periode pembentukan gigi;

g. Unsur kimia yang paling berpengaruh pada persentase karies gigi adalah fluor;

h. Pengaruh air ludah terhadap gigi sudah lama diketahui, terutama dalam mempengaruhi kekerasan email gigi. ${ }^{7}$

Penelitian ini bertujuan untuk memberikan gambaran karies gigi pada pasien karyawan P.T Freeport berdasarkan karakteristik umur dan jenis kelamin.

\section{METODOLOGI}

Jenis penelitian yang digunakan adalah penelitian deskriptif dengan menggunakan data sekunder berupa buku register penggunjung Instalasi gigi dan mulut di Rumah Sakit PT. Freeport Indonesia di Tembagapura. Penelitian deskriptif dengan survey morbiditas yang bertujuan untuk mengetahui kejadian dan distribusi penyakit di masyarakat atau populasi. ${ }^{8}$

\section{Waktu dan Tempat Penelitian}

1. Waktu penelitian yaitu pada minggu keempat di bulan Juni tahun 2020
2. Tempat penelitian di Instalasi gigi dan mulut Rumah Sakit PT Freeport Indonesia di Tembagapura

\section{Definisi Operasional}

1. Penyakit karies gigi adalah penyakit karies gigi yang merupakan kerusakan gigi yang terjadi di jaringan keras gigi mulai dari email gigi hingga akar gigi disebabkan oleh aktivitas jasad renik dalam suatu karbohidrat yang dapat di ragikan yang banyak terjadi pada orang dewasa.

3. Umur adalah usia pasien yang tercatat di buku register yang dijadikan sampel yaitu usia dewasa umur 15- $\geq 70$ tahun setiap kelompok

4. Jenis kelamin adalah perbedaan biologis antara laki-laki dan perempuan yang berkunjung untuk melakukan tindakan perawatan gigi tetap yang tercatat pada buku register di Instalasi gigi dan mulut Rumah Sakit PT Freeport Indonesia di Tembagapura tahun 2018-2019.

\section{Populasi dan Sampel}

1. Populasi

Populasi dalam penelitian yaitu data seluruh pasien yang memeriksakan gigi ke Instalasi gigi dan mulut Rumah Sakit PT Freeport Indonesia di Tembagapura mulai tahun 2018-2019 yang berjumlah $\mathbf{1 3 . 8 5 7}$ pasien.

2. Sampel

Sampel yang digunakan dalam penelitian ini yaitu seluruh pasien dengan penyakit karies dengan jumlah 13.472 pasien yang berkunjung di Instalasi gigi dan mulut Rumah Sakit PT Freeport Indonesia di Tembagapura tahun $2018-2019$

\section{InstrumenPenelitian}

Instrumen yang digunakan dalam penelitian ini yaitu buku register kunjungan 
pasien Instalasi gigi dan mulut Rumah Sakit PT Freeport Indonesia di Tembagapura, format pengisian data umur, jenis kelamin, alat tulis , seperti pensil, penghapus, pena, penggaris, kertas, dan buku mulai tahun 2018-2019.

\section{Teknik Pengumpulan Data}

Data yang digunakan dalam penelitian ini adalah data sekunder yaitu yang diperoleh dari dokumen atau buku register kunjungan pasien di Instalasi gigi dan mulut Rumah Sakit PT Freeport Indonesia di Tembagapura. selang tahun 2018-2019.

\section{HASIL}

\section{Gambaran Umum Lokasi Penelitian.}

Rumah Sakit PT Freeport Indonesia berkedudukan sebagai Rumah Sakit Umum yang dikelola oleh perusahaan swasta yang merupakan unsur pendukung operasi tambang PT Freeport Indonesia yang memiliki area operasi di Provinsi Papua, Kabupaten Mimika.

Rumah Sakit PT Freeport Indonesia adalah Rumah Sakit tipe D, dan tanggal 25 Agustus 2016 telah lulus akreditasi dengan peringkat perdana diketuai oleh dokter gigi Muhamad Syafril. Rumah Sakit PT Freeport Indonesia adalah sebuah rumah sakit nirlaba yang secara khusus didirikan dengan tujuan untuk merawat/memelihara dan meningkatkan derajat kesehatan karyawan PT Freeport Indonesia, Perusahaan Privatisasi dan Perusahaan Kontraktor beserta anggota keluarganya yang bertempat tinggal di daerah sangat terpencil di Tembagapura Kabupaten Mimika Provinsi Papua.Terkait dengan tujuan tersebut di atas maka PT Alas Emas Abadi sebuah perusahaan swasta nasional yang bergerak dalam bidang jasa pelayanan medis, ditunjuk oleh PT Freeport Indonesia untuk bertindak selaku pengelola Rumah Sakit PT Freeport Indonesia sejak tanggal 1 Oktober 1994 sampai saat ini.

\section{Karakteristik Responden}

Karyawan PT Freeport Indonesia sangat beragam terdiri dari berbagai suku bangsa baik dari dalam maupun luar negeri. Karyawan yang berasal dari luar negeri, meliputi dari Amerika, Canada, Australia, Afrika Selatan, Filipina dan India. Karyawan yang berasal dari dalam negeri meliputi antara lain Suku Batak, Minangkabau, Palembang, Betawi, Jawa, Sunda, Banten, Bali, Timor, Dayak, Manado, Toraja, Makasar, Bugis dan Papua. Suku Papua sendiri terdiri atas berbagai suku lagi, diantaranya adalah suku Papua Mimika yang tinggal di wilayah kontrak karya PT Freeport Indonesia. Suku Papua Mimika ini terdiri dari tujuh suku yaitu Suku Moni, Suku Amungme, Suku Damal, Suku Kamoro, Suku Dani, Suku Ekari dan Suku Duga. Tujuh suku ini difasilitasi oleh PT Freeport Indonesia baik secara ekonomi, kesehatan, dan pendidikan.

\section{Distribusi Karies Gigi Berdasarkan Kunjungan Pasien di Instalasi Gigi dan Mulut RS. PT Freeport Indonesia pada tahun 2018 dan tahun 2019}

Distribusi karies gigi berdasarkan kunjungan pasien di instalasi gigi dan mulut RS PT Freeport Indonesia pada tahun 2018-2019 dapat dilihat dari tabel 1 berikut ini :

Tabel 1. Distribusi Karies Gigi di instalasi gigi dan mulut RS PT Freeport Indonesia Tahun 2018-2019

\begin{tabular}{ccc}
\hline Tahun & $\begin{array}{c}\text { Jumlah Kunjungan } \\
\text { Pasien dengan } \\
\text { Karies }\end{array}$ & $\begin{array}{c}\text { Persentase } \\
\%\end{array}$ \\
\hline 2018 & 6671 & $49 \%$ \\
2019 & 6801 & $51 \%$ \\
\hline Total & 13.472 & $100 \%$ \\
\hline
\end{tabular}

Berdasarkan tabel 1 jumlah kunjungan pasien dengan kasus karies gigi di instalasi gigi dan mulut RS PT Freeport Indonesia terbanyak pada tahun 2019 sebanyak 6801(51\%) pasien dari pada tahun 2018 sebanyak 6671 (49\%)pasien. 


\section{Distribusi Karies Gigi Berdasarkan Umur Tahun 2018-2019}

Distribusi karies gigi berdasarkan umur dapat dilihat pada tabel 2 berikut ini:

Tabel 2. Distribusi Frekuensi Karies gigi berdasarkan umur di Instalasi gigi dan mulut RS PT Freeport Indonesia Tahun 2018 - 2019

\begin{tabular}{|c|c|c|c|}
\hline Tahun & $\begin{array}{c}\text { Umur } \\
\text { (Tahun) }\end{array}$ & Jumlah & $\begin{array}{c}\text { Persentase } \\
(\%)\end{array}$ \\
\hline \multirow{8}{*}{2018} & $15-21$ & 451 & $7,76 \%$ \\
\hline & $22-28$ & 1244 & $18,64 \%$ \\
\hline & $29-35$ & 1389 & $20,82 \%$ \\
\hline & $36-42$ & 1312 & $19,66 \%$ \\
\hline & $43-49$ & 1262 & $19,91 \%$ \\
\hline & $50-56$ & 893 & $13,38 \%$ \\
\hline & $57-63$ & 96 & $1,43 \%$ \\
\hline & $64-70$ & 24 & $0,35 \%$ \\
\hline & tal & 6671 & $100 \%$ \\
\hline \multirow{8}{*}{2019} & $15-21$ & 481 & $7,01 \%$ \\
\hline & $22-28$ & 1231 & $18,10 \%$ \\
\hline & $29-35$ & 1466 & $21,55 \%$ \\
\hline & $36-42$ & 1306 & $19,21 \%$ \\
\hline & $43-49$ & 1329 & $19,54 \%$ \\
\hline & $50-56$ & 910 & $13,38 \%$ \\
\hline & $57-63$ & 66 & $0,97 \%$ \\
\hline & $64-70$ & 12 & $0,17 \%$ \\
\hline \multicolumn{2}{|c|}{ Total } & 6801 & $100 \%$ \\
\hline
\end{tabular}

Berdasarkan tabel 2 menyatakan bahwa, distribusi karies gigi berdasarkan umur tertinggi tahun 2018 pada umur 29-35 tahun sebanyak 1389 pasien $(20,82 \%)$ dan tahun 2019 pada umur 29-35 tahun sebanyak 1466 pasien $(21,55 \%)$. Sedangkan karies gigi terendah tahun 2018 pada umur 64-70 tahun sebanyak 24 pasien $(0,35 \%)$ dan tahun 2019 pada umur 64-70 tahun sebanyak 12 pasien $(0,12 \%)$.

\section{Distribusi Karies Gigi Berdasarkan Jenis Kelamin}

Distribusi karies gigi berdasarkan jenis kelamin dapat dilihat pada tabel 3 di berikut ini.
Tabel 3. Distribusi Frekuensi Karies Gigi Berdasarkan Jenis Kelamin di Instalasi gigi dan mulut di RS PT Freeport Indonesia Tahun 2018-2019

\begin{tabular}{ccccccc}
\hline Jenis & \multicolumn{2}{c}{$\mathbf{2 0 1 8}$} & \multicolumn{2}{c}{$\mathbf{2 0 1 9}$} & \multicolumn{2}{c}{ Jumlah } \\
\cline { 2 - 7 } Kelamin & n & \% & n & \% & n & \% \\
\hline Laki-Laki & 5560 & 49,88 & 5586 & 50,12 & 11146 & 100 \\
\hline Perempuan & 1111 & 47,76 & 1215 & 52,24 & 2326 & 100 \\
\hline Total & 6671 & 49,52 & 6801 & 50,48 & 13472 & 100 \\
\hline $\begin{array}{c}\text { Sumber : Buku Register Kunjungan Pasien Poliklinik Gigi Rumah } \\
\text { Sakit PT Freeport Indonesia Tahun 2018 Dan Tahun 2019 }\end{array}$ &
\end{tabular}

Berdasarkan data pada tabel 3, distribusi data pasien dengan karies gigi berdasarkan karakteristik jenis kelamin tertinggi dari tahun 2018 - 2019 yaitu pada laki-laki dimana pada tahun 2018 data penderita karies gigi sebanyak 5560 pasien $(83,3 \%)$, dan tahun 2019 sebanyak 5586 pasien (82,2 \% ). Sedangkan terendah pada jenis kelamin perempuan tahun 2018 ada 1111 pasien (16,7 $\%)$ penderita karies gigi dan tahun 2019 sebanyak 1215 pasien $(17,8 \%)$.

\section{PEMBAHASAN}

Karies merupakan suatu penyakit jaringan keras gigi, yaitu email, dentin, dan sementum, yang disebabkan oleh aktivitas suatu jasad renik terhadap suatu karbohidrat yang dapat diragikan. Beberapa faktor yang mempengaruhi terjadinya karies gigi, antara lain: Keturunan, ras, jenis kelamin, usia, makanan, vitamin, unsur kimia, air ludah.

Berdasarkan hasil penelitian yang dilakukan di Instalasi gigi dan mulut RS PT Freeport Indonesia (tabel 1) didapatkan kunjungan penderita karies gigi meningkat di tahun 2019 yaitu sebanyak 6801. Hal ini terjadi karena bertambahnya karyawan baru Freeport sehingga meningkat kasus karies gigi dan peningkatan juga terjadi karena informasi dari pasien yang pernah mendapatkan 
perawatan di Instalasi gigi dan mulut RS PT Freeport Indonesia di Tembagapura tentang ketersediaan fasilitas penunjang pelayanan kesehatan gigi. Peningkatan kunjungan pasien kemungkinan karena disebabkan oleh pelayanan RS PT Freeport Indonesia semakin baik hingga lulus akreditasi. Kemudahan akses bagi karyawan PT Freeport juga menyebabkan kunjungan jadi bertambah. Pelayanan kesehatan yang berkualitas dan terbaik sangat dibutuhkan masyarakat untuk mengobati penyakit gigi dan mulut.

\section{Peningkatan kunjungan ini}

kemungkinan juga karena keberagaman jenis pelayanan dari RS PT Freeport, baik pencegahan primer, sekunder maupun tersier. Pencegahan primer yang dilakukan antara lain memberikan penyuluhan bagi pasien yang memperoleh pelayanan di poli gigi baik personal hygiene, jenis-jenis makanan yang menunjang kesehatan gigi maupun kebiasaan buruk yang perlu dihindari. Pemilihan topik penyuluhan berdasarkan kasus yang dihadapi pasien, sehingga kemungkinan pasien dapat melakukan pencegahan dengan kasus terkait, tetapi tidak dapat melakukan pencegahan kasus penyakit yang lain. Pencegahan sekunder yang dilakukan adalah dengan melakukan penumpatan/tambalan untuk mencegah keparahan gigi pada karyawan PT Freeport yang berkunjung ke Poli Gigi. Pada pasien yang mendapat pelayanan pencegahan sekunder, pasien mendapatkan penyuluhan untuk mempertahankan gigi selama mungkin dalam mulut, sehingga tidak berdampak pada rehabilitasi fungsi gigi.

Usia selalu terkait dengan masalah kesehatan gigi dan mulut dalam hal ini karies. Hasil penelitian menunjukan (tabel 2) distribusi karies gigi berdasarkan karakteristik umur tertinggi di tahun 2018 pada umur 29-35 tahun sebanyak 1389 pasien $(20,82 \%)$ sedangkan tahun 2019 tertinggi juga pada umur 29-35 tahun sebanyak 1466 pasien
(21,55\%). Pada usia ini biasanya orang-orang meninggalkan rumah untuk belajar atau bekerja di tempat lain. Kemungkinan juga penyebab tingginya karies gigi di usia ini karena kesibukan nanti melakukan pemeriksaan gigi kalau sudah ada keluhan sakit atau ngilu. ${ }^{9}$

Selain faktor usia, faktor jenis kelamin ikut mempengaruhi terjadinya karies gigi. Berdasarkan hasil penelitian (tabel 3) menunjukkan distribusi karies gigi berdasarkan karakteristik jenis kelamin pada tahun 2018-2019 tertinggi yaitu pada jenis kelamin laki-laki. Hal tersebut dikarenakan mayoritas karyawan Freeport Indonesia adalah jenis kelamin laki-laki. PT Freeport yang merupakan perusahaan tambang mineral di tanah Papua sehingga mayoritas pekerja tambang berjenis kelamin laki-laki sehingga jumlah pasien berjenis kelamin laki-laki yang memeriksakan di klinik PT Freeport lebih besar presentasenya dibandingkan perempuan.

\section{KESIMPULAN}

Berdasarkan penelitian yang dilakukan dapat disimpulkan bahwa distribusi karies gigi berdasarkan karakteristik pengunjung di Instalasi gigi dan mulut RS PT Freeport Indonesia sebagai berikut :

1. Distribusi karies pada pengunjung Instalasi gigi dan mulut tahun 2018-2019 mengalami peningkatan, di tahun 2019 dengan jumlah 6801 (51\%) kasus karies.

2. Distribusi berdasarkan karakteristik umur tertinggi tahun 2018-2019 yaitu pada kelompok umur 29-35 tahun, pada tahun 2018 sebesar 1389 pasien $(20,82 \%)$ dan tahun 2019 sebesar 1466 pasien $(21,55 \%)$

3. Distribusi karies berdasarkan karakteristik jenis kelamin tertinggi yaitu pada Lakilaki tahun 2018 sebesar 5560 pasien 
$(83,3 \%)$ dan tahun 2019 sebesar 5586 pasien ( $82 \%$ ).

\section{SARAN}

Rumah Sakit PT Freeport Indonesia diharapkan meningkatkan frekuensi dan intensitas promosi kesehatan memberikan pelayanan promotive dalam kontaks ini yang tekait dengan program kesehatan untuk mencegah karies gigi pada karyawan PT Freeport Indonesia.

\section{DAFTAR PUSTAKA}

1. Widayati, 2014. Faktro Yang Berhubungan Dengan Karies Gigi Pada Anak Usia 4-5 tahun. http://e-journal.unair.ac.id.

2. Tarigan, R., (2012). Karies Gigi. Edisi 2. EGC, Jakarta.

3. Kemenkes RI, (2013). Riset Kesehatan Dasar. Badan Penelitian dan Pengembangan Tenaga Kesehatan Kemenkes, Jakarta.

4. Pintauli, S, Hamada, T, (2014). Menuju Gigi dan Mulut Sehat. USU Press. Medan

5. Kid and Bechal.1992 Dasar-Dasar Karies Penyakit dan Penanggulangannya EGC Jakarta
6. Jayanti, C, D. 2012. Hubungan Tingkat Pengetahuan Ibu Tentang Karies Gigi dengan Kejadian Karies Karies Gigi Pada Anak TK Aisyiyah Kateguhanan Sawit Boyolali. Surakarta. Skripsi, UMS.

7. Tarigan, R., (2012). Karies Gigi. Edisi 2. EGC, Jakarta

8. Notoatmodjo, S, (2010). Promosi Kesehatan (Teori dan Aplikasi). Rineka Cipta, Jakarta.

9. Margareta, S. (2012). Tips 101 \& Terapi Alami Agar Gigi Putih dan Sehat. Pustaka Cerdas, Yogyakarta. 